\title{
Det Ustyrlige Klima \\ - Eksperternes vej fra forskere til flagellanter
}

Anmeldt af Jan Thøgersen, Kemisk Institut, Aarhus Universitet

"Alle taler om vejret, men ingen gør noget ved det" (red: Storm P.) - nu er der nogen, der prøver!

"Den politiske verdens forståelige ønske om klare svar fra forskerne samt stærke følelser knyttet til formodningen om menneskets skyld i de nutidige klimaændringer modarbejder desværre den normale videnskabelige proces frem mod et velbegrundet og nuanceret svar." Således indleder professor i fysisk geografi ved Oslo Universitet Ole Humlum sin nye bog "Det ustyrlige klima". Bogen omhandler, hvad vi ved - og navnlig ikke ved om sammenhængen mellem drivhusgasser og Jordens temperatur.

\section{Bogens inddeling}

"Det ustyrlige klima" er opdelt i otte kapitler. I de første to kapitler, som udgør knap halvdelen af bogen, beskriver Ole Humlum klimaets påvirkning af den europæiske og navnlig den danske kultur gennem de seneste 1.000 år. Sideløbende med beskrivelsen af det politiske europakort fletter Ole Humlum elegant klimaets indflydelse på Skagens historie ind i kapitlerne og får dermed gjort klimaets betydning meget nærværende.

Bogen giver først en interessant beskrivelse af, hvordan varmt vejr i Nordeuropa $i$ begyndelsen af forrige årtusinde medførte en betydelig forøgelse af høstudbyttet, som dermed var medvirkende til bedre levevilkår. I Alperne smeltede gletscherne og frilagde gamle kobberminer, så minedriften kunne genoptages, og vin kunne dyrkes 300-500 km nord for nutidens nordgrænse.

Hen imod år 1300 blev det varme vejr langsomt afløst af en koldere periode kendt som Den Lille Istid. Denne periode varede til slutningen af det 18 . århundrede, og det kolde vejr fik i flere tilfælde direkte indflydelse på den dramatiske udvikling af europakortet. Navnlig i krige fik det kolde vejr afgørende betydning, $\mathrm{fx}$ fordi kolde isvintre betød, at lande som Sverige og Danmark kunne indtages til fods over havisen. Ole Humlum imponerer med en spændende gennemgang af, hvordan vejret påvirkede krigene mellem Sverige og Danmark, Sverige og Rusland, Finland og Rusland, England

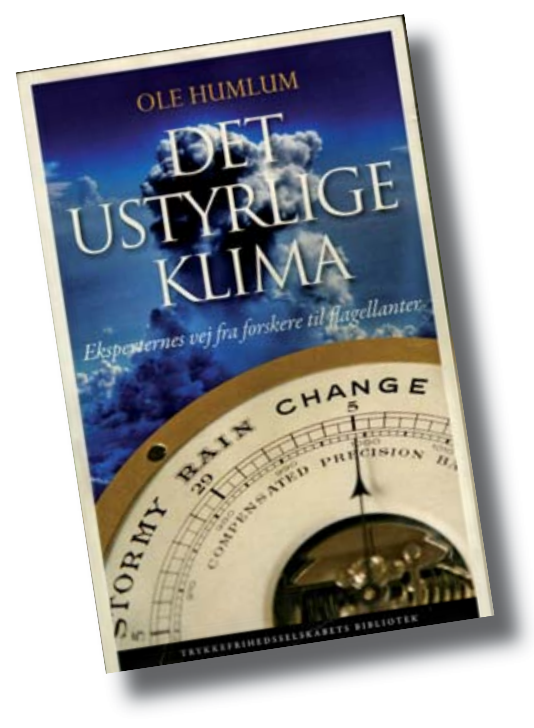

og Frankrig og selvfølgelig også Napoleons mildt sagt fejlslagne felttog til Moskva. Men vejret havde betydning for andet end krige. Da Den Lille Istid kulminerede omkring 1600-tallet, blev blandt andre England, Norge og Færøerne ramt af hungersnød som følge af ringe høst og fiskeri, og det europæiske befolkningstal stagnerede på grund af høj dødelighed.

\section{Ny varmeperiode}

I begyndelsen af 1800 tallet blev Europa igen varmere. Industrialisering tog sin begyndelse, og den deraf følgende forbrænding af kul tog fart. På denne tid var naturvidenskaben i rivende udvikling, og i 1886 fremsatte den svenske videnskabsmand Arrhenius sin hypotese om, at variationer i atmosfærens $\mathrm{CO}_{2}$-indhold kunne forklare de skiftende istider og mellemistider. Arrhenius var fuldstændigt klar over, at mange af de forhold, der bestemmer Jordens temperatur, var dårligt bestemte eller totalt ukendte på denne tid, men beregnede med disse forbehold en forøgelse af temperaturen på Arktis på 8-9 ${ }^{\circ} \mathrm{C}$ ved en 2,5-3 ganges forøgelse af atmosfærens $\mathrm{CO}_{2}$-indhold.

Femten år senere, i 1901, undersøgte en anden svensk forsker, Knut Ångstrøm, strålingsegenskaberne ved både $\mathrm{CO}_{2}$ og vanddamp, og han konkluderede, at en forøgelse af atmosfærens $\mathrm{CO}_{2}$-indhold kun vil have en ringe temperatureffekt. Opvarmningen fortsatte i 1900-tallet, hvor særligt perioden fra 1915-1940 prægedes af kraftig opvarmning. De norske gletschere skrumpede, og i Vestgrønland blev der ikke dannet fastis i fjordene på vestsiden af Disko øen $\left(70^{\circ} \mathrm{N}\right)$. Som følge af klimaforbedringen blev $\mathrm{CO}_{2}-$ hypotesen igen ført til torvs, men mange forskere mente fortsat, at mængden af atmosfærisk $\mathrm{CO}_{2} \mathrm{i}$ al væsentlighed blev holdt $\mathrm{i}$ skak af Henrys lov om gassers opløselighed i (hav-) vand, den globale temperatur samt en række geologiske, biologiske og oceanografiske processer.

Det varme vejr blev afløst af en køligere periode fra midten af 1940 'erne til sidst $i$ 1970 'erne. Klimazonerne flyttede sig mod ækvator, og Sahel-området syd for Sahara blev ramt af tørke, som alene i 1972-73 kostede 100.000 - 200.000 mennesker livet. $\mathrm{CO}_{2}$-hypotesen trådte gradvist $\mathrm{i}$ baggrunden, og World Meteorological Organisation (WMO) foreslog tiltag for at bremse den pågående klimaforværring! Men afkølingen blev efterfulgt af en periode med opvarmning, og i 1989 stiftedes IPCC (International Panel on Climate Change) på initiativ af blandt andet WMO. Formålet med IPCC er blandt andet at forsyne Verdens regeringer med argumenter for at reducere udslippet af $\mathrm{CO}_{2}$ med henblik på at undgå fremtidige uønskede klimaforandringer.

Med de to første kapitler har Ole Humlum slået fast, at temperaturen på Jorden (eller i hvert fald den del af den, vi har pålidelige data fra) har varieret mere igennem det forgangne årtusinde end i de seneste hundrede år. Ole Humlum konkluderer, at varmere vejr historisk set har betydet fremgang og velstand, mens kulde har medført hungersnød og stagnation.

\section{IPCC og $\mathrm{CO}_{2}$-indholdet}

I kapitel 3 tager Ole Humlum for alvor fat på den af IPCC påståede sammenhæng mellem atmosfærens indhold af $\mathrm{CO}_{2}$ og den globale temperatur. Ud over at bestemmelsen af både $\mathrm{CO}_{2}$-indholdet og den globale temperatur er behæftet med betydelig eksperimentel usikkerhed, er der, ifølge Ole Humlum, en lang række argumenter imod, at stigningen af $\mathrm{CO}_{2}$-indholdet $\mathrm{i}$ atmosfæren er menneskeskabt. For det første stiger atmosfærens indhold at $\mathrm{CO}_{2}$ kun lidt over halvt så meget, som forbrændingen af fossile brændstoffer skulle tilsige. For det andet optages $\mathrm{CO}_{2} \mathrm{i}$ stort omfang $\mathrm{i}$ verdenshavene 
og forsvinder derfor fra atmosfæren. Skulle den målte stigning i atmosfærens $\mathrm{CO}_{2}$-indhold derfor være menneskeskabt, skulle vi afbrænde langt mere fossilt brændstof end tilfældet er. For det tredje viser isotopsammensætningen af atmosfærens $\mathrm{CO}_{2}$, at kun ca. $5 \%$ at atmosfærens $\mathrm{CO}_{2}$ er menneskeskabt mod IPCCs påståede $28 \%$. For det fjerde ved man fra studiet af aske fra vulkaner og ${ }^{14} \mathrm{C}$ fra atombombesprængninger på den nordlige halvkugle, at disse partikler tager et par år om at blive ensartet fordelt over begge Jordens halvkugler. Indholdet af $\mathrm{CO}_{2}$ varierer derimod synkront nord og syd for ækvator, og det er tankevækkende, når $75 \%$ af al $\mathrm{CO}_{2}$ fra afbrændingen af fossile brændstoffer finder sted nord for $30^{\circ} \mathrm{N}$.

Ole Humlum fremdrager yderligere en række observationer og analyser i modstrid med argumentationen og konklusionerne i IPCCs rapporter fra både 2007 og 2009 , og kapitel 3 afrundes da også med at sætte spørgsmålstegn ved hele IPCC's videnskabelige objektivitet.

\section{Computermodeller}

For at se, hvordan klimaet udvikler sig i fremtiden, laver forskere Verden over computermodeller for den globale temperatur. Herom handler kapitel 4. Modellerne er baseret på fysiske, kemiske, geologiske, biologiske og antropologiske lovmæssigheder og parametre. Kompleksiteten af sådanne modeller er svimlende, og mange af de indgående parametre kendes kun dårligt. Derfor er modellernes forudsigelser behæftet med betydelig usikkerhed. Det ved forskerne bag modellerne udmærket, og de er - efter god videnskabelig skik - derfor meget omhyggelige med kun at omtale deres resultater som mulige fremtidsscenarier. Men når sådanne forudsigelser når frem til pressen, tilsidesætter journalisterne som oftest disse usikkerheder, og vi kan derfor næsten dagligt høre om kolossale forøgelser i den fremtidige globale temperatur med enorme oversvømmelser til følge.

Desværre, skriver Ole Humlum, forsøger forskerne bag resultaterne sjældent at falsificere deres resultater. Altså at finde eksperimentelle observable, der er i modstrid med modellernes forudsigelser. Det er dog ellers hele grundlaget for, om en model er troværdig eller må forkastes. I stedet gør man sig de største anstrengelser for at finde eksempler på, at modellernes forudsigelser er korrekte. " $\mathrm{CO}_{2}$-hypotesen forsvares med ad hoc-forsvarsmekanismer tilsyneladende uden tanke på, at hypotesen derved mister sin videnskabelige karakter og reduceres til et spørgsmål om tro", skriver Ole Humlum.

Ole Humlum fortsætter kapitlet med at gennemgå en række fejl, usikkerheder og manipuleringer af Jordens $\mathrm{CO}_{2}-$ og temperaturdata. Her skal blot nævnes to. Almindeligvis sammenlignes nutidens temperaturforhold med en såkaldt normaltemperatur, som er defineret ved gennemsnitstempera-

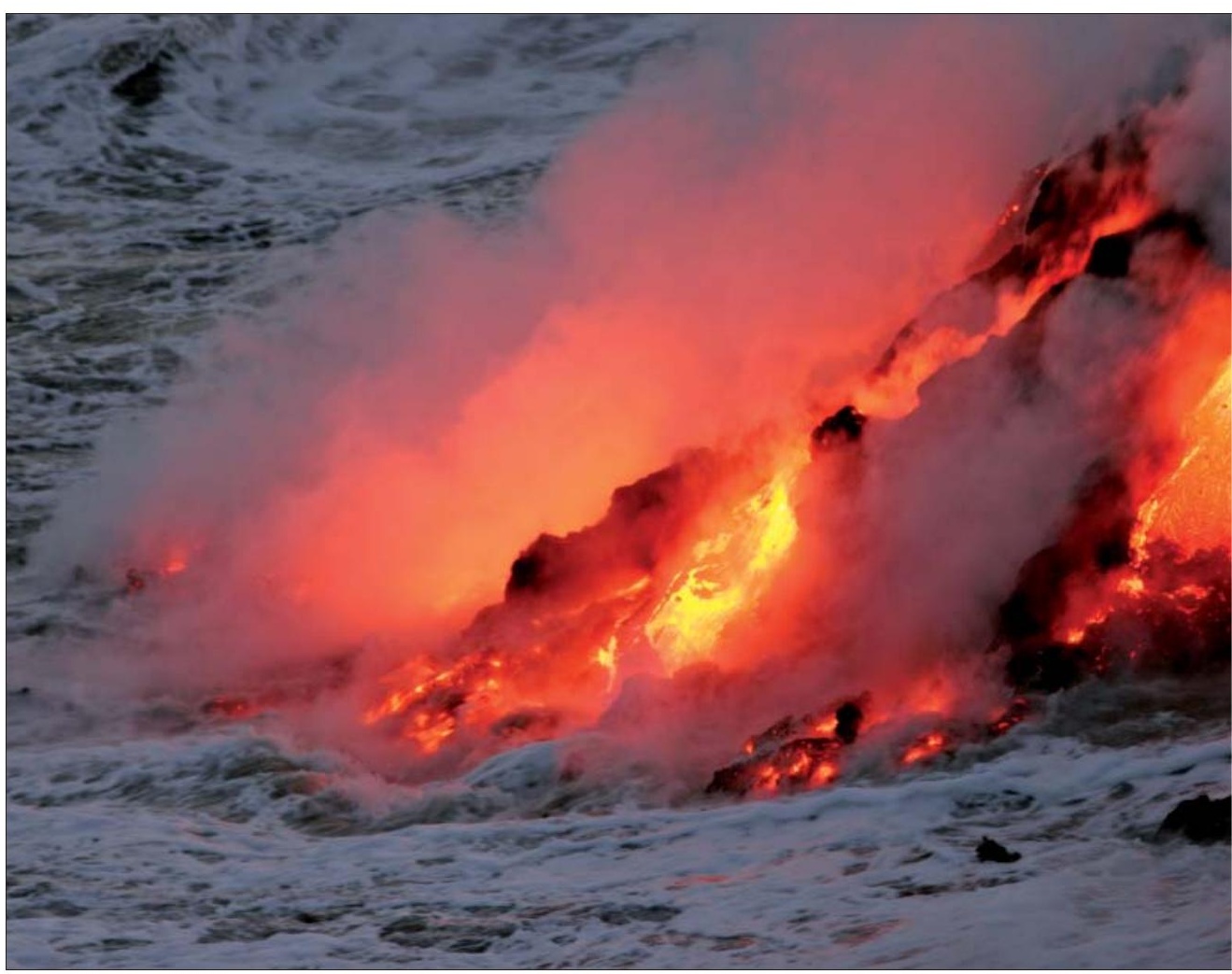

Ved et kraftigt vulkanudbrud, hvor der udsendes store mangder aske i atmosfceren, og hvor ekstra skydannelse derved virker afkølende på både atmosfcere og oceaner, vil oceanerne ifølge Henrys lov kunne optage mere $\mathrm{CO}_{2}$, hvilket skulle kunne forklare, hvorfor mangden af atmosfcerisk $\mathrm{CO}_{2}$ ikke steg scerligt meget $i$ år med kraftige vulkanudbrud som fx i 1991-92 under Pinatubo-udbruddet i Indonesien og i 1980 (Mount St. Helens-udbruddet, USA). (Foto af vulkanudbrud på Hawaii: Tom Pfeiffer)

turen fra 1961 til 1990. Men denne periode domineres af den relativt kolde periode fra 1961 til 1980. Havde man i stedet inddraget årene fra 1940 til 1961 i gennemsnittet, ville forskellen til nutidens temperatur være betydeligt mindre. Hvad angår $\mathrm{CO}_{2}$-dataene, er de sammensat af to kurver. Den ene kurve kommer fra direkte målinger foretaget efter 1958 ved vulkanen Mauna Loa på Hawaii, mens atmosfærens $\mathrm{CO}_{2}$-indhold før $1958 \mathrm{er}$ målt på iskerner. De to kurver passer bare ikke sammen, men giver et uregelmæssigt forløb, hvor $\mathrm{CO}_{2}$-indholdet i 1889 muligvis er lige så højt som i 1973. Dette var helt uventet for mange forskere og efter moden overvejelse, som den lune Humlum udtrykker det, valgte man at forskyde iskernedataene med 80 år, så kurven fik et mere glat forløb!

\section{Alternative klimaeksperter}

Kapitel 4 afrundes med at anføre, at politikere (fx Al Gore) og religiøse repræsentanter (fx Desmond Tutu) har overtaget rollerne som klimaeksperter. "Uden at være tynget af formel meteorologisk eller klimatologisk indsigt hævder de, at den videnskabelige diskussion om årsagen til nutiden klimaændringer er afsluttet". "Mennesket har syndet og pådraget sig skyld. Med stor $\mathrm{CO}_{2}$-udledning til følge rejser de moralsk bedrestillede omkring i Verden som en slags klimaflagel- lanter og forklarer ... den rette årsagssammenhæng for de stakkels syndere", skriver Ole Humlum. Efter bogens offentliggørelse har vi været vidne til, at danske biskopper har opfordret deres præster til klokkeringninger for klimaet. Det tør nok antydes, at Ole Humlum har en pointe.

Ole Humlum indleder kapitel 5 med at præcisere, at formodningen om en menneskeskabt klimakrise er baseret på en enorm mængde data opnået ved en respektindgydende indsats af forskere fra mange fagområder. Og selvom IPCC's rapporter indeholder fejl og mangler, kan de ikke uden videre affejes som tendentiøse. Men IPCC's brøde består i, at sammenfatningen af resultaterne er foretaget af folk, der er enige $i$ hypotesen om $\mathrm{CO}_{2}$-klimabetydningen - og det farver konklusionerne, hævder Ole Humlum.

\section{De psykologiske faktorer}

Kapitel fem omhandler endvidere de psykologiske faktorer, som fx gruppepres og autoritetstro, der er med til at skabe konsensus om $\mathrm{CO}_{2}$-hypotesen. Eksempelvis skal man i dag være $\mathrm{i}$ besiddelse af en ikke ringe videnskabelig selvtillid for at stille sig frem offentligt og tale $\mathrm{CO}_{2}$-hypotesen imod.

I et kort kapitel 6 spørger Ole Humlum om, hvordan vi er endt $i$ en situation, hvor eksperimentelle data tilsidesættes eller forvrænges til fordel for fastholdelsen af en 
hypotese. Ole Humlum søger selv svaret i, hvordan forskningen fra politisk side forsøges styret af hensynet til særlige interesser gennem øremærkning af bevillinger til særlige formål. "Universiteterne må styre deres egen udvikling og må under ingen omstændigheder ende som forlængede udviklingslaboratorier for erhvervslivet eller som støtteapparater for forskellige politiske initiativer", pointerer Ole Humlum.

Det fremføres ofte i den daglige debat, at vi bliver nødt til at reducere $\mathrm{CO}_{2}$-indholdet i atmosfæren nu, også selvom det senere skulle vise sig, at den globale temperatur ikke påvirkes nævneværdigt af den menneskeskabte $\mathrm{CO}_{2}$. Risikoen ved ikke at gøre noget er simpelthen for stor. Det er det såkaldte forsigtighedsprincip, og herom handler kapitel 7. Her anfører Ole Humlum, at forsigtighedsprincippet anvendt på klimaet kan have drastiske konsekvenser for nationale og internationale økonomier, og særligt i en tid med økonomisk krise kan et påbud om reduktion af energiforbruget og indføring af $\mathrm{CO}_{2}$-afgifter få vidtrækkende konsekvenser. "De otte molboer, der bar hyrden ind på kornmarken for at jage storken væk, handlede også efter forsigtig- hedsprincippet”, hedder det i bogen.

Også for videnskaben vil forsigtighedsprincippet få alvorlige følger. Hvis det om 10-15 år går op for Verden, at $\mathrm{CO}_{2}$-hypotesen var en and, vil videnskabsfolk uanset standpunkt i klimadebatten få et troværdighedsproblem i offentligheden, skriver han. Herved vil senere fremkomne sande resultater og konklusioner naturligvis blive mødt med offentlig skepsis.

I bogens sidste kapitel gør Ole Humlum status over den nuværende debat med udgangspunkt i IPCC's modeller af den globale temperaturs fremtidige forløb. Ifølge Ole Humlum ser IPCC's forudsigelser af en kraftigt stigende temperatur ud til at være $\mathrm{i}$ stadigt større modstrid med de faktiske forhold. Det ser dog ikke ud til at påvirke den førte politik, siger Humlum, fordi der nu er lagt så meget prestige i $\mathrm{CO}_{2}$-hypotesen, at politikere og andre aktører har bestemt sig for at gennemføre vidtrækkende politiske indgreb, uanset hvad den virkelige verden måtte vise om den faktiske udvikling. Som anført $i$ indledningen må en nuanceret behandling af videnskabelige resultater altså vige for en allerede bestemt politisk dagsorden.

\section{Men hvor er referencelisten?}

Ole Humlums analyse og argumentation bygger bogen igennem på videnskabelige undersøgelser. Derfor er det overraskende, at bogen ikke har en litteraturliste. Tilmed refererer Ole Humlum enkelte steder til udsagn fra unavngivne "eksperter". Der er ingen tvivl om, at Ole Humlum ligger inde med et særdeles omfattende kildeapparat, og bogens argumenter ville helt klart stå stærkere, hvis der i højere grad blev henvist til navngivne kilder. Det ændrer dog ikke ved, at Ole Humlum har skrevet en særdeles læseværdig bog, der med stort vid og lune giver læseren et indblik i klimatiske forhold, man sjældent hører om i den daglige presse. Bogen er trykt på Trykkefrihedsselskabets bibliotek, som er kendt for at have modet til at trykke bøger af forfattere med kontroversielle synspunkter.

Det Ustyrlige Klima af Ole Humlum udkom på Trykkefrihedsselskabet sidst $i$ november 2009. 181 sider. Andet oplag er udsolgtnyt oplag overvejes. Pris: 175,00 kr. ISBN: 978-87-92417-08-4.

\section{Vulkan i udbrud}

Vulkanen Mayon på Filippinerne er begyndt at udspy akse. I byen Legazpi i Albay-provinsen ca. $500 \mathrm{~km}$ syd for Manila begyndte sikkerhedsstyrker 18/12 at evakuere tusinder af indbyggere fra deres huse og gårde.

$J P / S L J$

\section{Nordsøen som $\mathrm{CO}_{2}$-lager}

En ny banebrydende $\mathrm{CO}_{2}$-teknik kan med stor sandsynlighed øge udvindingen i de kendte oliefelter, hvor Mærsk Olie og Gas borer. Teknikken går ud på, at $\mathrm{CO}_{2}$ fra kraftværker på land pumpes over i tankskibe, som sejler ud til olieplatforme i Nordsøen, hvor $\mathrm{CO}_{2}$ pumpes ned i oliebrønde. Ved en kemisk proces vil mere olie kunne presses ud af kridtlagene.

Det anslås, at der vil kunne hentes op til 50 procent mere olie op af felterne, samtidig med at $\mathrm{CO}_{2}$ lagres i undergrunden. Når der ikke mere kan udvindes olie af brøndene i
Nordsøen lukkes hullerne, og $\mathrm{CO}_{2}$ 'en bliver i undergrunden.

Før projektet kan igangsættes, kræves der imidlertid, at kraftværkerne investerer i en teknologi, som kan filtrere de udledte røggasser, således at $\mathrm{CO}_{2}$ 'en isoleres og afsondres. Alt tyder på, at EU-kommissionen vil subventionere projektet.

$J P / S L J$

\section{Danmark storforbruger af kul}

Danmark er blandt Verdens største forbrugere af kul målt pr. indbygger. Siden 2005 har hver dansker i gennemsnit brugt 3,6 kilo kul om dagen. Danske kraftværkers og varmeværkers primære energikilde er kul, når danskerne skal forsynes med elektricitet og varme. Der importeres mere end 7 mio. tons kul om året, hvilket bringer Danmark op blandt de allerstørste forbrugere af kul i Verden målt pr. indbygger.

Danmarks største energikoncern Dong
Energy udledte i 2009638 gram $\mathrm{CO}_{2}$ for hver produceret kilowatt-time. I 2020 er målet, at $\mathrm{CO}_{2}$-udledningen kan nedbringes til 320 gram.

Ifølge Kyoto-protokollen skal Danmark reducere $\sin \mathrm{CO}_{2}$-udledning med $21 \%$ inden 2012 målt $i$ forhold til udledningen i 1990. $\mathrm{CO}_{2}$-kvoter kan dog købes i de landes, som ikke har opbrugt deres eller ved at investere i udenlandske klimaprojekter, som efterfølgende godskrives i det danske kilmaregnskab, således at måles nås.

$J P / S L J$

\section{Drivende isbjerg}

Et 150 meter langt isbjerg med en højde på op mod 30 meter meldes på vej mod New Zealand. Skibe i den sydlige del af Stillehavet advares om isbjerge, som kommer drivende fra Antarktis. 